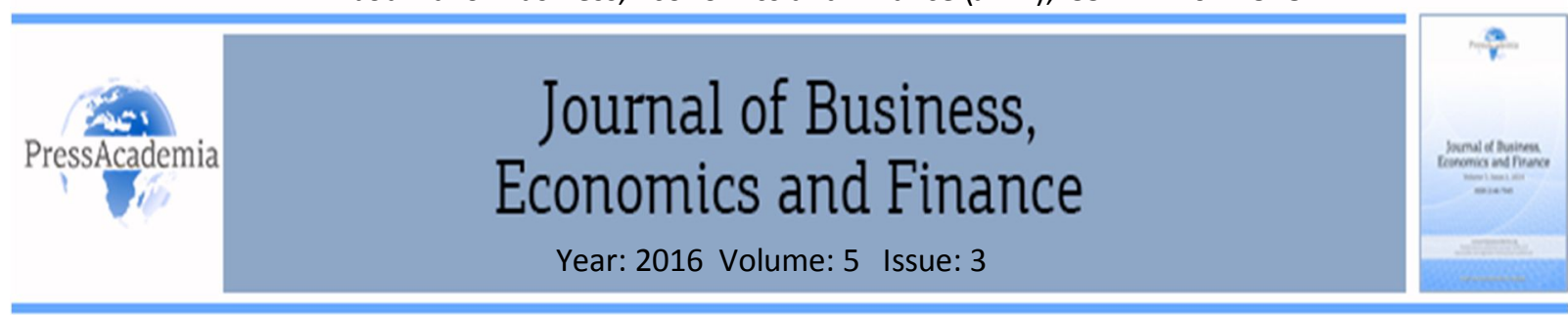

\title{
QUALITIES REQUIRED BY SME BUSINESSES IN TECHNICAL STAFF IN CASE OF CRISIS: WOODWORKING INDUSTRY SAMPLE
}

\section{DOI: 10.17261/Pressacademia.2016321973}

\author{
Mehmet Colak ${ }^{1}$, Tahsin Cetin ${ }^{2}$ \\ ${ }^{1}$ Mugla Sitki Kocman University, cmehmet@mu.edu.tr \\ ${ }^{2}$ Mugla Sitki Kocman University, tahsincetin@mu.edu.tr
}

\begin{abstract}
Owners and/or managers of the small enterprises who are obliged to take the responsibility of making decisions at times of crises due to the very nature of these enterprises should have a perspective of strategic thinking and should be able to make an accurate analysis of the internal and external environments in order to overcome the crisis with minimal loss and damage. Sought qualifications are having information in automatisation with computer programs (Autocad, CAD/CAM, Solidworks etc.), practical technical detail and construction, having an innovative and entrepreneur structure, being able to make innovative design and produce solutions, knowing more than one foreign language, and being able to use CNC machines. It is seen that the enterprises in question have taken precautions for improving the quality of the innovative products and increasing the labour productivity as well as for reducing the costs in such periods.
\end{abstract}

Keywords: SME, woodworking, production

JEL Classification: D20, J00, 015

\section{INTRODUCTION}

In our time, importance of educated person according to countries has become crucial to stand against intense competition with globalization tendencies. Human force which can adopt changing conditions, which can understand technological application, which are productive, which can communicate with environments, which can perform teamwork, which have profession information and skill constitute the basic force in development of a country (Icli, 2007). As education is a societal process, it is inevitable for this process to affect the development of economic life. Continuous education can contribute to increasing the efficiency of workforce, development of manufacturing system and well-fare of the society. The contribution of education to production and economy can be rendered through vocational education and training. Thus, a nation's production capacity can be increased by means of developing schooling ratio, education system, quality of the system, introduction of the graduates to the labor market, their recruitment and using their existing potential (Tasindi, 1999).

Small and medium sized enterprises (SME) are considered to be at the heart of the economic and social life all over the world since they can adapt to demand diversifications easily by creating more product variety with less investment, because they contribute to the interregional balanced development and employment significantly, are complementary of big sized enterprises as supplier industry and are affected by economic fluctuations (Kaygin and at al., 2008). Businesses and environment influence entail various threats and crises which organizations may face. Due to the devastating effects of crisis, coping skill of managers, in terms of organization is essential. To manage crisis, problems need to be identified in advance, as a way to prevent them from occurring; rather than to take steps to limit their consequences. As can be seen it is better to predict 
and prevent crises from occurring or steps should be taken to limit their results, if they cannot be stopped (Colak, 2013).

Small and medium sized enterprises (SMEs) and family businesses are encouraged to be institutionalized to overcome the problems associated with uncertainty and growth. It seems that the term is attached variety of different meanings in Turkish context, very far from the original institutional theory. Even fundamental organizational principles and generally accepted business practices are suggested as methods towards institutional transformation (Ulukan, 2005).

\section{LITERATURE REVIEW}

Both in our country and in the world, there are many educational institutions constructed under various names to meet the need of furniture industry for qualified technical staff. These different educational institutions are responsible for training individuals with different qualifications determined by laws. Standards related to location, personnel, premises, facilities, equipments, tools and capacities of these educational institutions are set in advance and the institutions are constructed according to these standards to function optimally and efficiently (Anonymous 1, 2015).

The furniture industry is a labour-intensive and dynamic sector dominated by small and medium-sized enterprises (SMEs) and micro firms. Turkey furniture manufacturers have a good reputation worldwide thanks to their creative capacity for new designs and responsiveness to new demands. The industry is able to combine new technologies and innovation with cultural heritage and style, and provides jobs for highly skilled workers (Anonymous 2, 2016).

For a firm to conduct its activities within the principles of being economical, it needs to turn inputs into outputs in an efficient and effective manner. The purpose of the managerial staff is to fulfill the objectives of the organization. Moreover, the organization's adjustment to constantly changing environmental conditions and changing the existing structure when necessary is a requirement of the contemporary view of management. Hence, managerial staff is of great importance for the future of an organization (Burdurlu, 2004).

Firms have a special need for intermediate staff and they try to meet this need by means of in-service training they offer within the organization. This partially reduces the need for intermediate workers but not enough for the posts requiring higher level of education (Kaya, 2004).

Miller and Colleagues (2002) classified problems experienced by SMEs as follows:

- Finance procurement,

- Lowering general administrative expenses,

- Lowering employee expenses,

- State regulations and laws,

- Finding and holding qualified employee,

- Pricing of products and services,

- Development of marketing strategy.

One of important problems of small and medium-sized enterprises is the failure to find qualified employee and training problem. Problems in finding qualified employee cause these businesses not to have adequate effect in phases such as planning, standard, production, and quality control and not to reach desired competitive capacity. Personnel and training problems have a distinct importance for small and medium-sized enterprises. The fact that such businesses do not always make the same kind of work necessitates that employee to be hired makes various works. For instance, those working in an industry section making diverse manufactures need to be in montage one day, in lathe-levelling another day, and in welding work still another day. The fact that these businesses are generally labor-intensive businesses increases qualified employee necessity. The most important factor in failure to find qualified employees by small and medium-sized enterprises are 
irregular payment policies and failure to provide sufficient social insurance to employees. As a result, trained employees leave for large-scale businesses (Anonymous 3, 2015).

Problems confronted with in vocational education result in shortage of qualified personnel, unemployment and lack of experience. These problems adversely affect the development and competitive power of the industry. In the Membership Declaration of the European Union, it is stated that development of vocational education policy of Turkey should be a priority for the sector (TUCCE, 2012).

There is a shortage of qualified personnel in the sector. Especially the shortage of CNC and wood processing operators in the production is worth special consideration. Though some vocational training courses are initiated by Turkish Employment Agency (TEA), there is not much demand for these courses. Vocational high school graduates do not prefer to work in workshops. The novice workers start with minimum wage then the wage gradually increases over years. It is important to resolve the problems of vocational high schools (e.g. instructor, equipment etc.) (MBSDA, 2013).

Qualifications desired to be found in employees to be hired by business authorities are:

- Basic skills and workforce literacy,

- Planning, decision-making, critical thinking and problem solving skills,

- Communication skill,

- Work ethics, administrative and leadership skills,

- Professional skill and computer using skill (Icli, 2007).

Vocational high school graduates do not prefer to work in workshops. The novice workers start with minimum wage then the wage gradually increases over years. It is important to resolve the problems of vocational high schools (e.g. instructor, equipment etc.) (MBSDA, 2013).

Factors affecting the training of qualified workforce can be stated as follows (Aktan, 2005);

- Increase in the speed to transition from order-focused production to mass-production,

- Furniture sector's maintaining its labor-intense characteristic,

- As most of the firms in the sector are family businesses, employment ratio of qualified personnel is low,

- In some certain parts of small and medium scale organizations, works are done by unqualified personnel,

- Problems in the employers' viewpoint of personal development and training,

- Lack of in-service training,

- Limited utilization of institutionalization mechanism,

- Inability to meet the needs and expectations of qualified personnel,

- Inadequate number of firms offering social security in the sector.

Every type of crisis can lead to spontaneous distortion of the interaction between humans, technology and other elements of the organization. First of all, crisis is a state which is unexpected and not easy to detect by the organization. There may be some signals of crisis. Yet, what is important at that point is that the organization should be able to recognize the signals and take measures to avert a crisis by displaying great sensitivity towards environmental changes (Tutar, 2000).

Turkish furniture industry is mostly composed of small and medium enterprises (SEMs) and these SEMs are mostly family businesses and managed by family members. In these organizations, the ratio of professional managers and qualified workforce is low (Anonymous 4, 2015). 


\section{DATA AND METHODOLOGY}

Today, Turkish furniture industry mostly consists of small-scale organizations using traditional production methods. However, particularly within the last 15-20 years, the number of the middle- and large-scale organizations has increased. The important centers of furniture production are; Istanbul, Ankara, Bursa (Inegol), Kayseri, Izmir and Adana (Sakarya, 2006). Firms in the furniture industry can be found in many cities of the country. In terms of the number of formally registered furniture manufacturing companies and employment level, Istanbul takes the first place. The number of organizations manufacturing furniture in Istanbul is 3874 and it is followed by Ankara with 1971 organizations and then by Izmir with 1474 organizations. The total number of the furniture manufacturing organizations in these three cities makes nearly half of all the furniture manufacturing organizations in Turkey. In terms of the level of employment, the number of people working in the furniture manufacturing companies in Istanbul is 21.653 and it is followed by Bursa with 13.994 and Kayseri with 11.390 (MBSDA, 2013). Within the context of the current study, four cities (Ankara, BursaInegol, Kayseri, Izmir) were randomly selected and the reasons for the selection of these cities are given below.

Ankara has always been an important center of furniture production. The most popular furniture production area of Ankara is called "Siteler" and it was established in 1960 with the initiation of the Chamber of Carpenters and now it is a big organized industrial site situated on 5000-decare area. There are many small and medium scale organizations operating in this site. The number of formally registered firms in this site is believed to be more than 10000. However, these firms are labor-intense organizations and the number of large scale firms is relatively small. According to the statistics issued by Turkish Statistical Institute (TSI), the number of workers per organization is 2,7 in the furniture sector of Ankara and this is lower than the average of Turkey. Another city where furniture production is intense is Bursa-Inegol Region and it is quite dynamic. It is located on the historical Silk Road and close to the sources of raw materials and the region has taken the advantages of its location and turned into a center of furniture production. In terms of the employment figures of the sector, Bursa-Inegol comes after Ankara. Yet, in relation to export figures, it takes the third place after Kayseri and Istanbul. Its success in export proves that it is on the way of becoming an international center of furniture manufacturing. Kayseri is one of the important centers of furniture production activities. The rise of Kayseri in the furniture sector started with the production of sofas, armchairs and beds. With the developments in technology and new investments, firms started to manufacture in every field of furniture sector and thus turned the city into an important furniture production center. According to the data issued by Turkish Union of Chambers and Commodity Exchanges (TUCCE) and export figures reported by TSI, Kayseri hosts the biggest furniture manufacturing organizations. The data reported by Kayseri Chamber of Carpenters, Furniture Dealers and Upholsterers show that the number of firms operating in the sector is more than 3500 . Nearly 400 of these firms are performing fabrication mass production and exporting. According to data issued by TSI, the number of workers employed by per firm is 11,5 and this is over the Turkish average. In 2011, the amount of export is worth 322 million dollars and this makes Kayseri one of the most important furniture production and export center(MBSDA, 2013).

In the current study, the data were collected through a questionnaire including 10 items to elicit the demographic features of the participants and 10 items related to expectations from the personnel and problems. This questionnaire was administered to 66 furniture manufacturing firms from Izmir, Ankara, Kayseri and Bursa (Inegol) to determine the expectations of employers from their workers in furniture manufacturing industry and the problems they are confronted with.

\section{FINDINGS AND DISCUSSIONS}

As can be seen in Table 1; the production issues of the organizations are as follows: 15 of them are woodwork, 42 are panel furniture and 9 are design office and applications. The number of personnel is as follows: 21 have fewer than 10 workers, 15 have 10-19 workers and 30 have 20 or more workers. When the length of the organizations' functioning in the sector is examined, it is seen that 12 of them have been operating for $0-4$ years, 9 of them for 5-10 years and 45 of them for 10 years or more. Of the organizations, 39 export. The number of the organizations using CNC machines is 30 . The number of organizations having a R\&D unit is 48 . This shows the importance attached to R\&D by the organizations. Of the organizations, 39 have sales outlets. 
The number of organizations having cooperation with educational institutions is 21 . The number of organizations believing that the decrease in the importance attached to vocational and technical education has increased the shortage of qualified workers is 57 . All of the organizations are recruiting technical personnel.

Table 1: Assessment Analysis of Business

\begin{tabular}{lccc}
\hline Evaluation Questions & Variables & $\mathbf{n}$ & Percent(\%) \\
\hline Production issues of the organizations & Woodwork & 15 & 22,8 \\
& Panel furniture & 42 & 63,6 \\
The number of workers in the organizations & Design Office and application & 9 & 13,6 \\
& 10 'than down & 21 & 31,8 \\
& $10-19$ between & 15 & 22,7 \\
The length of the organization's functioning in & 20 years or more & 30 & 45,5 \\
the sector & --4 Years & 12 & 18,2 \\
& $5-10$ Years & 9 & 13,6 \\
Does your organization export? & 10 Years or more & 45 & 68,2 \\
& Yes & 39 & 59,1 \\
Is a CNC machine used in the organization? & No & 27 & 40,9 \\
& Yes & 30 & 45,5 \\
Is there a Re\&De department in the & No & 36 & 54,5 \\
organization? & Yes & 48 & 72,7 \\
Does the organization have a sales outlet? & No & 18 & 27,3 \\
& Yes & 39 & 59,1 \\
Is there cooperation $\quad$ with $\quad$ educational & Yes & 27 & 40,9 \\
institutions? & No & 45 & 31,8 \\
Does the decreasing importance attached to & Yes & 57 & 86,4 \\
vocationals and technical education increase the & No & 9 & 13,6 \\
shortage of gualified personnel? & & & \\
Is it important to recruit technical personnel in & Yes & 66 & 100 \\
the organization? & No & 0 & 0 \\
\hline
\end{tabular}

As can be seen in Table 2, the organizations' expectations from their existing and prospective personnel can be expressed as follows according to order of importance; mastery in computer programs (72,7\%) (Q1), knowledge about technical details and construction $(68,2 \%)(06)$ and taking initiatives in the organizations $(68,2 \%)(Q 7)$, ability to persuade $(63,6 \%)(Q 4)$ and understanding of innovative designs (63,6\%) (Q5), following technological developments $(59,1 \%)(Q 9)$ and competence in marketing $(59,1 \%)(Q 2)$, close attention to the problems of staff and coming up with solutions (45,5\%) (Q8), mastery of foreign languages (40,9\%) (Q3). The least requested qualification is the use of CNC machines (27,3\%) (Q10). When the qualifications expected from existing and prospective personnel are statistically analyzed, it is seen that the most requested qualifications are knowledge about technical details and construction (Q6) and taking initiatives in the organization (Q7) and the least requested qualifications are mastery of foreign languages and (Q3) and use of CNC machines (Q10). 
Table 2: Expectation Level Analysis from Employees of Businesses

\begin{tabular}{|c|c|c|c|c|c|c|c|c|c|c|c|c|c|}
\hline \multirow[t]{2}{*}{ Expectations } & \multirow[t]{2}{*}{$\mathbf{N}$} & \multirow[t]{2}{*}{ M. } & \multirow[t]{2}{*}{ S. d. } & \multicolumn{2}{|c|}{$\begin{array}{l}\text { Not } \\
\text { important } \\
\text { at all }\end{array}$} & \multicolumn{2}{|c|}{$\begin{array}{c}\text { Not } \\
\text { important }\end{array}$} & \multicolumn{2}{|c|}{ Undecided } & \multicolumn{2}{|c|}{ Important } & \multicolumn{2}{|c|}{$\begin{array}{c}\text { Very } \\
\text { important }\end{array}$} \\
\hline & & & & $\mathrm{n}$ & $\%$ & $\mathrm{n}$ & $\%$ & $\mathrm{n}$ & $\%$ & $\mathrm{n}$ & $\%$ & $\mathrm{n}$ & $\%$ \\
\hline $\begin{array}{l}\text { Q1: Competence in computer } \\
\text { programs }\end{array}$ & 66 & 4,64 & 71 & 0 & 0 & 3 & 4,5 & 0 & 0 & 15 & 22,7 & 48 & 72,7 \\
\hline Q2: Competence in marketing & 66 & 4,18 & 1,23 & 3 & 4,5 & 9 & 13,6 & 0 & 0 & 15 & 22,7 & 39 & 59,1 \\
\hline $\begin{array}{l}\text { Q3: Mastery of foreign } \\
\text { languages }\end{array}$ & 66 & 3,82 & 1,27 & 3 & 4,5 & 12 & 18,2 & 6 & 9,1 & 18 & 27,3 & 27 & 40,9 \\
\hline Q4: Ability to persuade & 66 & 4,45 & 84 & 0 & 0 & 3 & 4,5 & 6 & 9,1 & 15 & 22,7 & 42 & 63,6 \\
\hline $\begin{array}{l}\text { Q5: Understanding of } \\
\text { innovative design }\end{array}$ & 66 & 4,54 & ,72 & 0 & 0 & 3 & 4,5 & 0 & 0 & 21 & 31,8 & 42 & 63,6 \\
\hline $\begin{array}{l}\text { Q6: Knowledge about technical } \\
\text { details and construction }\end{array}$ & 66 & 4,68 & ,46 & 0 & 0 & 0 & 0 & 0 & 0 & 21 & 31,8 & 45 & 68,2 \\
\hline $\begin{array}{l}\text { Q7: Taking initiatives in the } \\
\text { organization }\end{array}$ & 66 & 4,68 & ,46 & 0 & 0 & 0 & 0 & 0 & 0 & 21 & 31,8 & 45 & 68,2 \\
\hline $\begin{array}{l}\text { Q8: Close attention to the } \\
\text { problems of staff and coming } \\
\text { up with solutions }\end{array}$ & 66 & 4,36 & 64 & 0 & 0 & 0 & 0 & 6 & 9,1 & 30 & 45,5 & 30 & 45,5 \\
\hline $\begin{array}{ll}\text { Q9:Following } & \text { technological } \\
\text { developments }\end{array}$ & 66 & 4,59 & 49 & 0 & 0 & 0 & 0 & 0 & 0 & 27 & 40,9 & 39 & 59,1 \\
\hline Q10:Use of CNC machines & 66 & 3,41 & 1,27 & 3 & 4,5 & 18 & 27,3 & 12 & 18,2 & 15 & 22,7 & 18 & 27,3 \\
\hline
\end{tabular}

When the relationship between the length of the organizations' functioning in the sector and their expectations from their existing and prospective personnel is considered, it is seen that the high majority of the organizations operating in the sector for 10 years or more think that taking initiatives is very important. The organizations operating for 0-4 and 5-10 years attach relatively less importance to these qualifications; yet, they regard them as important. When the relationship between the length of functioning in the sector and expectations for the qualifications of having knowledge about technical details and construction and taking initiatives in the organization is examined, it is seen that all of the organizations view them as important qualifications to be possessed by their workers. When the relationship between the length of functioning in the sector and expectation for the qualification of following technological developments is examined, it is seen that while 21 of the organizations operation for 0-4 and 5-10 years find this qualification important, all of the 45 organizations operating for 10 years or more regard it as important. In relation to the use of CNC machines, 12 of the organizations operating for 0-4 and 5-10 years are undecided or view it as not important and 21 of the organizations operating for 10 years or more are also undecided or think that it is not important.

Table 3: Analysis of Activity Periods with Respect to Expectations

\begin{tabular}{|c|c|c|c|c|c|c|c|c|c|}
\hline \multirow{2}{*}{$\begin{array}{l}\text { Length of functioning } \\
\text { Expectations }\end{array}$} & \multirow[b]{2}{*}{ Importance level } & \multicolumn{2}{|c|}{$0-4$ Years } & \multicolumn{2}{|c|}{ 5-10 Years } & \multicolumn{2}{|c|}{$\begin{array}{l}10 \text { Years or } \\
\text { more }\end{array}$} & \multicolumn{2}{|c|}{ Total } \\
\hline & & $\mathrm{n}$ & $\%$ & $\mathrm{n}$ & $\%$ & $\mathrm{n}$ & $\%$ & $\mathrm{n}$ & $\%$ \\
\hline \multirow{6}{*}{$\begin{array}{l}\text { Understandingof } \\
\text { innovative design }\end{array}$} & Not important at all & 0 & 0 & 0 & 0 & 0 & 0 & 0 & 0 \\
\hline & Not important & 0 & 0 & 0 & 0 & 3 & 6,7 & 3 & 4,5 \\
\hline & Undecided & 0 & 0 & 0 & 0 & 0 & 0 & 0 & 0 \\
\hline & Important & 3 & 25 & 3 & 33,3 & 15 & 33,3 & 21 & 31,8 \\
\hline & Very important & 9 & 75 & 6 & 66,7 & 27 & 60 & 42 & 63,7 \\
\hline & Total & 12 & 18,2 & 9 & 13,6 & 45 & 68,2 & 66 & 100 \\
\hline \multirow{3}{*}{$\begin{array}{l}\text { Knowledge about } \\
\text { technical details and } \\
\text { construction }\end{array}$} & Not important at all & 0 & 0 & 0 & 0 & 0 & 0 & 0 & 0 \\
\hline & Not important & 0 & 0 & 0 & 0 & 0 & 0 & 0 & 0 \\
\hline & Undecided & 0 & 0 & 0 & 0 & 0 & 0 & 0 & 0 \\
\hline
\end{tabular}




\begin{tabular}{llllllllll} 
& Important & 3 & 25 & 3 & 33,3 & 15 & 33,3 & 21 & 31,8 \\
& Very important & 9 & 75 & 6 & 66,7 & 30 & 66,7 & 45 & 68,2 \\
& Total & 12 & 18,2 & 9 & 13,6 & 45 & 68,2 & 66 & 100 \\
\hline Taking initiatives in the & Not important at all & 0 & 0 & 0 & 0 & 0 & 0 & 0 & 0 \\
organization & Not important & 0 & 0 & 0 & 0 & 0 & 0 & 0 & 0 \\
& Undecided & 0 & 0 & 0 & 0 & 0 & 0 & 0 & 0 \\
& Important & 3 & 25 & 3 & 33,3 & 15 & 33,3 & 21 & 31,8 \\
& Very important & 9 & 75 & 6 & 66,7 & 30 & 66,7 & 45 & 68,2 \\
& Total & 12 & 18,2 & 9 & 13,6 & 45 & 68,2 & 66 & 100 \\
\hline Following technological & Not important at all & 0 & 0 & 0 & 0 & 0 & 0 & 0 & 0 \\
developments & Not important & 0 & 0 & 0 & 0 & 0 & 0 & 0 & 0 \\
& Undecided & 0 & 0 & 0 & 0 & 0 & 0 & 0 & 0 \\
& Important & 3 & 25 & 6 & 66,7 & 18 & 40 & 27 & 40,9 \\
& Very important & 9 & 75 & 3 & 33,3 & 27 & 60 & 39 & 59,1 \\
& Total & 12 & 18,2 & 9 & 13,6 & 45 & 68,2 & 66 & 100 \\
\hline Use of CNC machines & Not important at all & 0 & 0 & 0 & 0 & 3 & 6,7 & 3 & 4,5 \\
& Not important & 3 & 25 & 6 & 66,7 & 9 & 20 & 18 & 27,3 \\
& Undecided & 3 & 25 & 0 & 0 & 9 & 20 & 12 & 18,2 \\
& Important & 3 & 25 & 3 & 33,3 & 9 & 20 & 15 & 22,7 \\
& Very important & 3 & 25 & 0 & 0 & 15 & 33,3 & 18 & 27,3 \\
& Total & 12 & 18,2 & 9 & 13,6 & 45 & 68,2 & 66 & 100 \\
\hline
\end{tabular}

High majority of the participants ( $n=48,72,7 \%$ ) from all the posts in the organizations think that competency in computer programs is a very important qualification and some of them $(n=18,27,3 \%)$ think that having the skill of using CNC machines is very important. When we look at the expectation for the qualification of innovative design conception, it is seen that 18 of the production managers find it important or very important and 21 of the designers find it important or very important but in other posts, this ratio decreases to a great extent. Moreover, in relation to qualifications of having knowledge about technical details and construction, taking initiatives and following technological developments, it is seen that 42 of the production managers and designers attach greater importance.

Table 4. Evaluation of the Relationship between the Posts in the Organizations and Their Expectations

\begin{tabular}{|c|c|c|c|c|c|c|c|c|c|c|c|c|c|}
\hline \multirow{2}{*}{$\begin{array}{l}\text { Units of Study } \\
\text { Expectations }\end{array}$} & \multirow[b]{2}{*}{$\begin{array}{l}\text { Importance } \\
\text { level }\end{array}$} & \multicolumn{2}{|c|}{$\begin{array}{l}\text { Production } \\
\text { Manager }\end{array}$} & \multicolumn{2}{|c|}{ Designer } & \multicolumn{2}{|c|}{$\begin{array}{l}\text { Personnel } \\
\text { Manager }\end{array}$} & \multicolumn{2}{|c|}{$\begin{array}{l}\text { General } \\
\text { Manager }\end{array}$} & \multicolumn{2}{|c|}{ Others } & \multicolumn{2}{|c|}{$\begin{array}{l}\text { General } \\
\text { Total }\end{array}$} \\
\hline & & $\mathrm{n}$ & $\%$ & $\mathrm{n}$ & $\%$ & $n$ & $\%$ & $\mathrm{n}$ & $\%$ & $n$ & $\%$ & $n$ & $\%$ \\
\hline \multirow[t]{6}{*}{$\begin{array}{l}\text { Competence } \\
\text { computer } \\
\text { programs }\end{array}$} & $\begin{array}{l}\text { Not } \\
\text { important at } \\
\text { all }\end{array}$ & 0 & 0 & 0 & 0 & 0 & 0 & 0 & 0 & 0 & 0 & 0 & 0 \\
\hline & $\begin{array}{l}\text { Not } \\
\text { important }\end{array}$ & 3 & 14,3 & 0 & 0 & 0 & 0 & 0 & 0 & 0 & 0 & 3 & 4,6 \\
\hline & Undecided & 0 & 0 & 0 & 0 & 0 & 0 & 0 & 0 & 0 & 0 & 0 & 0 \\
\hline & Important & 3 & 14,3 & 3 & 14,3 & 0 & 0 & 3 & 100 & 6 & 33,3 & 15 & 22,7 \\
\hline & $\begin{array}{l}\text { Very } \\
\text { important }\end{array}$ & 15 & 71,4 & 18 & 85,7 & 3 & 100 & 0 & 0 & 12 & 66,7 & 48 & 72,7 \\
\hline & Total & 21 & 100 & 21 & 100 & 3 & 100 & 3 & 100 & 18 & 100 & 66 & 100 \\
\hline \multirow[t]{4}{*}{$\begin{array}{l}\text { Understanding of } \\
\text { innovative design }\end{array}$} & $\begin{array}{l}\text { Not } \\
\text { important at } \\
\text { all }\end{array}$ & 0 & 0 & 0 & 0 & 0 & 0 & 0 & 0 & 0 & 0 & 0 & 0 \\
\hline & $\begin{array}{l}\text { Not } \\
\text { important }\end{array}$ & 3 & 14,3 & 0 & 0 & 0 & 0 & 0 & 0 & 0 & 0 & 3 & 4,6 \\
\hline & Undecided & 0 & 0 & 0 & 0 & 0 & 0 & 0 & 0 & 0 & 0 & 0 & 0 \\
\hline & Important & 6 & 28,6 & 3 & 14,3 & 0 & 0 & 0 & 0 & 12 & 66,7 & 21 & 31,8 \\
\hline
\end{tabular}




\begin{tabular}{|c|c|c|c|c|c|c|c|c|c|c|c|c|c|}
\hline & $\begin{array}{l}\text { Very } \\
\text { important }\end{array}$ & 12 & 57,1 & 18 & 85,7 & 3 & 100 & 3 & 100 & 6 & 33,3 & 42 & 63,6 \\
\hline & Total & 21 & 100 & 21 & 100 & 3 & 100 & 3 & 100 & 18 & 100 & 66 & 100 \\
\hline \multirow[t]{6}{*}{$\begin{array}{l}\text { Knowledge about } \\
\text { technical details } \\
\text { and construction }\end{array}$} & $\begin{array}{l}\text { Not } \\
\text { important at } \\
\text { all }\end{array}$ & 0 & 0 & 0 & 0 & 0 & 0 & 0 & 0 & 0 & 0 & 0 & 0 \\
\hline & $\begin{array}{l}\text { Not } \\
\text { important }\end{array}$ & 0 & 0 & 0 & 0 & 0 & 0 & 0 & 0 & 0 & 0 & 0 & 0 \\
\hline & Undecided & 0 & 0 & 0 & 0 & 0 & 0 & 0 & 0 & 0 & 0 & 0 & 0 \\
\hline & Important & 15 & 71,4 & 0 & 0 & 0 & 0 & 0 & 0 & 6 & 33,3 & 21 & 31,8 \\
\hline & $\begin{array}{l}\text { Very } \\
\text { important }\end{array}$ & 6 & 28,6 & 21 & 100 & 3 & 100 & 3 & 100 & 12 & 66,7 & 45 & 68,2 \\
\hline & Total & 21 & 100 & 21 & 100 & 3 & 100 & 3 & 100 & 18 & 100 & 66 & 100 \\
\hline \multirow[t]{6}{*}{$\begin{array}{l}\text { Taking initiatives } \\
\text { in the } \\
\text { organization }\end{array}$} & $\begin{array}{l}\text { Not } \\
\text { important at } \\
\text { all }\end{array}$ & 0 & 0 & 0 & 0 & 0 & 0 & 0 & 0 & 0 & 0 & 0 & 0 \\
\hline & $\begin{array}{l}\text { Not } \\
\text { important }\end{array}$ & 0 & 0 & 0 & 0 & 0 & 0 & 0 & 0 & 0 & 0 & 0 & 0 \\
\hline & Undecided & 0 & 0 & 0 & 0 & 0 & 0 & 0 & 0 & 0 & 0 & 0 & 0 \\
\hline & Important & 9 & 42,9 & 3 & 14,3 & 0 & 0 & 0 & 0 & 9 & 50 & 21 & 31,8 \\
\hline & $\begin{array}{l}\text { Very } \\
\text { important }\end{array}$ & 12 & 57,1 & 18 & 85,7 & 3 & 100 & 3 & 100 & 9 & 50 & 45 & 68,2 \\
\hline & Total & 21 & 100 & 21 & 100 & 3 & 100 & 3 & 100 & 18 & 100 & 66 & 100 \\
\hline \multirow[t]{6}{*}{$\begin{array}{l}\text { Following } \\
\text { technological } \\
\text { developments }\end{array}$} & $\begin{array}{l}\text { Not } \\
\text { important at } \\
\text { all }\end{array}$ & 0 & 0 & 0 & 0 & 0 & 0 & 0 & 0 & 0 & 0 & 0 & 0 \\
\hline & $\begin{array}{l}\text { Not } \\
\text { important }\end{array}$ & 0 & 0 & 0 & 0 & 0 & 0 & 0 & 0 & 0 & 0 & 0 & 0 \\
\hline & Undecided & 0 & 0 & 0 & 0 & 0 & 0 & 0 & 0 & 0 & 0 & 0 & 0 \\
\hline & Important & 6 & 28,6 & 6 & 28,6 & 0 & 0 & 0 & 0 & 15 & 83,3 & 27 & 40,9 \\
\hline & $\begin{array}{l}\text { Very } \\
\text { important }\end{array}$ & 15 & 71,4 & 15 & 71,4 & 3 & 100 & 3 & 100 & 3 & 16,7 & 39 & 59,1 \\
\hline & Total & 21 & 100 & 21 & 100 & 3 & 100 & 3 & 100 & 18 & 100 & 66 & 100 \\
\hline \multirow[t]{6}{*}{$\begin{array}{l}\text { Use of } \\
\text { machines }\end{array}$} & $\begin{array}{l}\text { Not } \\
\text { important at } \\
\text { all }\end{array}$ & 3 & 14,3 & 0 & 0 & 0 & 0 & 0 & 0 & 0 & 0 & 3 & 4,5 \\
\hline & $\begin{array}{l}\text { Not } \\
\text { important }\end{array}$ & 3 & 14,3 & 6 & 28,6 & 0 & 0 & 0 & 0 & 9 & 50 & 18 & 27,3 \\
\hline & Undecided & 3 & 14,3 & 6 & 28,6 & 0 & 0 & 0 & 0 & 3 & 16,7 & 12 & 18,2 \\
\hline & Important & 6 & 28,6 & 6 & 28,6 & 0 & 0 & 0 & 0 & 3 & 16,7 & 15 & 22,7 \\
\hline & $\begin{array}{l}\text { Very } \\
\text { important }\end{array}$ & 6 & 28,6 & 3 & 14,3 & 3 & 100 & 3 & 100 & 3 & 16,7 & 18 & 27,3 \\
\hline & Total & 21 & 100 & 21 & 100 & 3 & 100 & 3 & 100 & 18 & 100 & 66 & 100 \\
\hline
\end{tabular}


As can be seen in Table 5, 75\% of 12 organizations operating for 0-4 years, 33,3\% of 9 organizations operating for 5-10 years and $80 \%$ of 45 organizations operating for 10 years or more have R\&D units and all of 12 organizations operating for 0-4 years, all of 9 organizations operating for $5-10$ years and $46,7 \%$ of 45 organizations operating for 10 years or more work in cooperation with educational institutions.

\begin{tabular}{|c|c|c|c|c|}
\hline \multirow{2}{*}{$\begin{array}{l}\text { The length of the organization's funtioning in the } \\
\text { sector }\end{array}$} & \multicolumn{3}{|c|}{ Re\&De Departmen } & \multirow[t]{2}{*}{ Total } \\
\hline & Freguency & Yes & No & \\
\hline \multirow[t]{2}{*}{$\underline{0-4}$ Years } & $\mathbf{n}$ & 9 & 3 & 12 \\
\hline & $\%$ & 75 & 25 & 100 \\
\hline \multirow[t]{2}{*}{ 5-10 Years } & $\mathbf{n}$ & 3 & 6 & 9 \\
\hline & $\%$ & 33,3 & 66,7 & 100 \\
\hline \multirow[t]{2}{*}{10 Years or more } & $\mathbf{n}$ & 36 & 9 & 45 \\
\hline & $\%$ & 80 & 20 & 100 \\
\hline \multirow{2}{*}{$\begin{array}{l}\text { The length of the organization's functioning in the } \\
\text { sector }\end{array}$} & \multicolumn{3}{|c|}{ School-Industry Collaboration } & Total \\
\hline & Freguency & Yes & No & \\
\hline \multirow[t]{2}{*}{$\underline{0-4 \text { Years }}$} & $\mathbf{n}$ & 0 & 12 & 12 \\
\hline & $\%$ & 0 & 100 & 100 \\
\hline \multirow[t]{2}{*}{$\underline{5-10 \text { Years }}$} & $\mathbf{n}$ & 0 & 9 & 9 \\
\hline & $\%$ & 0 & 100 & 100 \\
\hline \multirow[t]{2}{*}{10 Years or more } & $\mathbf{n}$ & 21 & 24 & 45 \\
\hline & $\%$ & 46,7 & 53,3 & 100 \\
\hline
\end{tabular}

As can be seen in Table 6, all of 15 organizations manufacturing woodwork (100\%), 42,9\% of 42 organizations manufacturing panel furniture and $33,3 \%$ of 9 organizations working in the field of design office applications work in cooperation with educational institutions and 36 of 48 organizations having R\&D units find their personnel's having the skill of following technological developments very important and 12 of them find it important; 3 of the organizations not having R\&D units find it very important and 15 of them find it important.

Table 6: Analysis of School-Industry Cooperation with Production Subject \& Analysis of Following Technology with R\&D department

\begin{tabular}{|c|c|c|c|c|}
\hline \multirow[t]{2}{*}{ Production issues of the organizations } & \multicolumn{3}{|c|}{ School-Industry Collaboration } & \multirow[t]{2}{*}{ Total } \\
\hline & Freguency & Yes & No & \\
\hline \multirow[t]{2}{*}{ Woodwork } & $\mathbf{n}$ & 0 & 15 & 15 \\
\hline & $\%$ & 0 & 100 & 100 \\
\hline \multirow[t]{2}{*}{$\underline{\text { Panel Furniture }}$} & $\mathbf{n}$ & 18 & 24 & 42 \\
\hline & $\%$ & 42,9 & 57,1 & 100 \\
\hline \multirow[t]{2}{*}{ Design Office and Application } & $\mathbf{n}$ & 3 & 6 & 9 \\
\hline & $\%$ & 33,3 & 66,7 & 100 \\
\hline \multirow[t]{2}{*}{ Re\&De unit in the organization } & \multicolumn{3}{|c|}{ Following Technological Developments } & Total \\
\hline & Freguency & Important & Very Important & \\
\hline \multirow[t]{2}{*}{$\underline{\text { Yes }}$} & $\mathbf{n}$ & 12 & 36 & 48 \\
\hline & $\%$ & 25 & 75 & 100 \\
\hline \multirow[t]{2}{*}{$\underline{\text { No }}$} & $\mathbf{n}$ & 15 & 3 & 18 \\
\hline & $\%$ & 83,3 & 16,7 & 100 \\
\hline
\end{tabular}

According to Table 7, $65.6 \%$ of the enterprises take precaution against crises while $34.44 \%$ of them do not take precautions against crises. While employees work overtime in $70.8 \%$ of the enterprises, $72 \%$ of the enterprises state that they prefer those having professional certificates while hiring employees. The rate of the enterprises that consider emerging crisis environments as opportunity is $57.3 \% .66 \%$ of the enterprises make internal situation analysis while $53.1 \%$ of them prefer qualified labour force. $61.5 \%$ of them stock products 
while $59.4 \%$ of the enterprises do not consider competitive environment as crisis threat. As for the methods used in determining the wages paid to the personnel, $38.5 \%$ of the enterprises take work performance as basis while $32.3 \%, 14.6 \%$ and $6.3 \%$ of the enterprises take minimum wage, contract and number of pieces produced as basis, respectively.

Table 7: Enterprise Crisis Situation Assessment Analysis

\begin{tabular}{|c|c|c|c|c|}
\hline Scale Variables & $\begin{array}{l}\text { Frequence } \\
\text { (f) }\end{array}$ & $\begin{array}{l}\text { Percent } \\
\text { (\%) }\end{array}$ & $\begin{array}{l}\text { Applicable } \\
\text { Percentage }\end{array}$ & $\begin{array}{l}\text { Cumulative } \\
\text { Percentage }\end{array}$ \\
\hline \multicolumn{5}{|l|}{ Crisis Management } \\
\hline \multicolumn{5}{|c|}{ Is there any precaution that you take against crisis? } \\
\hline Yes & 63 & 64,9 & 65,6 & 65,6 \\
\hline No & 33 & 34,0 & 34,4 & 100,0 \\
\hline \multicolumn{5}{|c|}{ Do employees overwork (overtime) in your enterprise? } \\
\hline Yes & 68 & 70,1 & 70,8 & 70,8 \\
\hline No & 28 & 28,9 & 29,2 & 100,0 \\
\hline \multicolumn{5}{|c|}{ Do you look for professional certificates (journeyman-mastership certificate) while hiring your employees? } \\
\hline Yes & 69 & 71,1 & 71,9 & 71,9 \\
\hline No & 27 & 27,8 & 28,1 & 100,0 \\
\hline \multicolumn{5}{|c|}{ Do you make internal situation analysis as a precaution in cases of crises? } \\
\hline Yes & 64 & 66,0 & 66,7 & 66,7 \\
\hline No & 32 & 33,0 & 33,3 & 100,0 \\
\hline \multicolumn{5}{|c|}{ Do you see any potential crisis environment as opportunity? } \\
\hline Yes & 55 & 56,7 & 57,3 & 57,3 \\
\hline No & 41 & 42,3 & 42,7 & 100,0 \\
\hline \multicolumn{5}{|c|}{ Which labour force do you prefer in your production? } \\
\hline Low-cost labour & 7 & 7,2 & 7,3 & 7,3 \\
\hline Qualified & 51 & 52,6 & 53,1 & 60,4 \\
\hline Both & 38 & 39,2 & 39,6 & 100,0 \\
\hline \multicolumn{5}{|c|}{ Is competition environment a crisis threat for you? } \\
\hline Yes & 39 & 40,2 & 40,6 & 40,6 \\
\hline No & 57 & 58,8 & 59,4 & 100,0 \\
\hline \multicolumn{5}{|c|}{ According to what do you determine the changes in the wages of the employees? } \\
\hline Work performance & 37 & 38,1 & 38,5 & 38,5 \\
\hline Amount determined by the state & 31 & 32,0 & 32,3 & 70,8 \\
\hline Contract & 14 & 14,4 & 14,6 & 85,4 \\
\hline Amount produced & 6 & 6,2 & 6,3 & 91,7 \\
\hline Desire of the employees & 8 & 8,2 & 8,3 & 100,0 \\
\hline Total & 96 & 99,0 & 100,0 & \\
\hline
\end{tabular}

While the number of insured personnel ranged between 5 and 10 prior to the crisis, this number reached 10-20 after the crisis. While the number of uninsured personnel was between 20 and 30 prior to the crisis, this number dropped to 10-20 after the crisis. The number of unqualified personnel was 10-20 prior to the crisis while the range expanded and number became 20-30 after the crisis. Export production of the enterprises was $20-30 \%$ prior to the crisis while it reduced following the crisis and regressed to $10-20 \%$. While the import rate of the enterprises ranged between $10-20 \%$ prior to the crisis, it changed considerably and exceeded $50 \%$. While enterprises do not take precautions against crises before the crisis, they take precautions following the crisis. While the enterprises wanted their employees to work overtime before the crisis, they did not want overwork after the crisis. While executives did not pay bonuses to the personnel before the crisis, they started to pay after the crisis. The 21st century -together with the radical changes in the work life dynamics and the emergence of conceptual knowledge, globalization, competition and new generations- has brought highly different lifestyle compared to previous ones.

Furniture industry that was traditionally labor-intense and working with low technology and capital is progressing towards being an industry that is relatively more information and capital-focused. The most important reason behind this transition is its undergoing a fast globalization process. Particularly the 
disadvantage of small and medium-scale organizations operating in the sector is the lack of the competitive advantage of technology, qualified personnel, design, school-industry collaboration and marketing.

Businesses give importance that hired employees are equipped with sufficient information and skills, can keep pace with rapidly changing and developing technological innovations, and are individuals open to constant learning. Basic qualifications sought in an employee to be hired by business authorities can be ranked as; being responsible, representative skill, persuasion ability, being initiative, communication skill, planning, decisionmaking and problem-solving skills, adapting to professional ethic principles, having professional competence.

SME managements do not give importance to professional management approach. Owner, partner and/or manager of many businesses regard what have been learned by observations as adequate and they believe that they can constantly maintain their works with success.

Businesses stated that they first looked for good-humored personnel for peace of working environments, and then they wanted people to be hired as honest, hardworking, reliable, respectful, disciplined and prompt. Business owners give importance that employees to be hired are able to be use computer. Moreover, they want the employee to apply for job to be graduate of at least vocational school level, and to have certificates in accountancy, office programs, foreign language and diction, mainly a computer certificate. Lastly, businesses stated that they did not find education provided in vocational schools adequate; in accordance with obtained results, it was suggested that authorities having voices in their fields should consider these problems and initiate activities for solution of these problems.

All of the organizations attach great importance to the recruitment of technical personnel. Training of qualified human force that can enable societal development to occur can be ensured to a great extent through the education system. Qualified labor force is an inevitable element of an efficient economy. The way of having qualified labor force is a well-planned vocational education. Vocational and technical education is of vital importance to emerging economies. When the expectations from the existing and prospective personnel can be put into order of importance as follows; mastery in computer programs $(72,7 \%)$, information about technical details and construction and taking initiatives in the organization $(68,2 \%)$ and skill of persuasion and understanding of innovative designs $(63,6 \%)$. The qualification least expected from personnel is the ability of using CNC machines (27,3\%). When the qualifications expected from existing and prospective personnel are statistically analyzed, it is seen that the most requested qualifications are knowledge about technical details and construction and taking initiatives in the organization and the least requested qualifications are mastery of foreign languages and and use of CNC machines. While the organizations consider possessing technical information and innovative ideas to be important, they do not attach much importance to foreign language competence and skill of using CNC machines. The organizations mostly export products and the ratio of design information export in general export figures is too small.

As a result, there is a need to make attempts to establish better corporation between the sector and educational institutions, to provide better computer technologies education and to train more qualified labor force to meet the requirements of the age. What should be done by organizations is to get ready for a crisis and the adverse effects it will create, take the required measures, develop pre-emptive alert systems, manage the chaotic situation to be created by a crisis successfully and minimize the effect of a crisis. The required measures should be planned by organizations within the framework of "crisis management" before a crisis starts. Special attention should be taken not to destroy the future of the organization just to save the day (Colak, 2013).

\section{CONCLUSION}

Moreover qualified worker problem can be overcome easily through university-industry cooperation. There are a lot of Vocational High Schools providing furniture education all over the country. If the enterprises cooperate with these schools qualified students can be determined just during practical training and can be employed after graduation. The enterprises must increase the proportion of employing engineers and give priority to the forest industrial engineers and wood products industrial engineers for furniture sector. A legal arrangement can be recommended for this subject. Accordingly, employing at least one woodworking industrial engineer must become a legal compulsion for medium sized enterprises (Kaygin and at al., 2008). Education is the most 
important power of development. A educated person is an important resource in gaining competation superiority. Nowadays the firms need personals who can catch up with the changing conditions, cope with the techonological practices, productive, owning communicative ability, cooperative to increase the power of competation. As in developed countries, there should be a stronger cooperation between the sector and universities, new furniture design departments can be opened at locations of intense furniture production, more academic research should be conducted on furniture industry and plans and programs need to be developed to enhance the cooperation between educational institutions and the sector. Vocational training in the sector of furniture manufacturing should be rendered more attractive and this is believed to contribute to the solution of the basic problems and the development of the sector.

Informing workers about up-to-date issues concerning effective and efficient production, following cuttingedge technologies, bringing innovations to the fields of application, elimination of potential deficiencies of experience and provision of training courses on the issues requiring specialization can enhance the existing skills and knowledge. Developing projects with development agencies, giving more active roles to adult education centers, increasing the amount of in-service training will enable workers to enhance their skills and experiences. It may be enabled that education and consultancy supports are provided in order that SME owners/managers can have a vision and strategical thinking can be enabled, thereby enabling them to have a corporate structure. Within this framework, in relation to university-industry cooperation development, it will be beneficial to add a legal dimension rather than voluntariness. SMEs have great problems in supplying qualified employee. This kind of businesses require versatile qualified employee more due to reasons such as being relatively high labor-intensive, and necessity to make different works in accordance with orders.

Qualified job vacancy in Turkish industry comprises a wide variety from apprentice-assistant master-master to vocational school graduates. Education programs for meeting qualified employee need comprise apprenticeassistant master-master and technical and administrative employees In diverse subjects and interventions. Within this framework, education level and education of personnel are also important. Education can generally provide benefits to organizations such as increase in work efficiency, morale boosting in the organization, decrease in control activities, decrease in working accidents, and continuation and compliance in business organization.

New education programs should be established for the training of designers in the sector. University-sector collaboration should be strengthened; in this way, both the quality of universities can be improved and qualified personnel need of the sector will be reduced. Consequently, training employees in accordance with expectations of changing and developing furniture sector and necessity of bringing permanent and innovative solutions to encountered problems are set forth.

\section{REFERENCES}

Aktan, C.C. 2005, 'Information Management in the Information Age', Lens Publications, MESS, April.

Anonymous 1, 2015, http://www.haberler.com/mobilya-sektorunde-kalifiye-eleman-bulunamiyor-3625462-haberi/(Access Date 17.02.2015).

Anonymous 2, 2016, http://www.izto.org.tr/portals/0/iztogenel/dokumanlar/isletmelerde_kriz_yonetimi_ii_h_baran_26.04.2012\%202309-02.pdf (Access Date: 06.04.2016).

Anonymous 3, 2015, http://tiponaybelgesi.net/projedt/377-kobilerin-karsilastiklari-isletmecilik-sorunlari.html (Access Date: 21.05.2015)

Anonymous 4, 2015, http://www.orsiad.com.tr/mobilya-sektorunun-sorunlari-ve-cozum-onerileri.html (Access Date 10.01.2015).

Burdurlu, E. 2004 'Administrative Personnel Preferences of Turkey Furniture Industry', G.U. Journal of Science, ISSN 1303-9709, 17(1): 85100.

Colak, M. 2013, 'Being affected from crisis: Case of furniture industry in Turkey', African Journal of Business Management, Vol. 7(1), 78-84, 7 January, 2013.

Icli, G, 2007, 'Vocational School of Business Alumni Related Opinion and Expectations', Marmara University, I.I.B.F. Journal, Vol: XXIII, Num: 2, Istanbul.

Kaya, Y.K. 2004, 'Education Management Theory and Practice in Turkey', TODAIE Publications, Ankara. 
Kaygin, B. \& Tankut, A.N. and Cayli, M. 2008, 'The structural analysis of small and medium size furniture enterprises in Turkey based on production, capacity use and working environment', African Journal of Biotechnology, Vol. 7 (24), pp. 4628-4634, 17 December 2008.

MBSDA, 2013, 'Middle Black Sea Development Agency', Wood Products and Furniture Industry Report, Vol:27, Samsun.

Miller, N.J. \& Besser, T.L., Gaskill, L.R. and Sapp, S.G. 2002 'Community and Managerial Predictors of Performance in Small Rural US Retail and Service Firms', Journal of Retailing and Consumer Services, Vol: 10 (4), 215-230.

Sakarya, S. 2006, 'Evaluation Report for the Furniture Industry Middle Anatolia Exporters', Union Secretariat, January Issue, pp.1-51.

Tasındi, A. S. 1999, “Determination of training needs in Central and Upper Management”, Human Reseource Journal, March.

Tutar, H. 2000, 'Management in Crisis and Stress Environment', Hayat Publishing, 14, Istanbul.

TUCCE, 2012, Turkish Union of Chambers and Commodity Exchanges, Assembly of the Sector Report Turkey Furniture Products, V:18, Ankara.

Ulukan, C. 2005, 'Perspectives of Institutionalization of Entrepreneurs and Professional Managers', Magazine of Social Sciences, 2, Turkey. 